
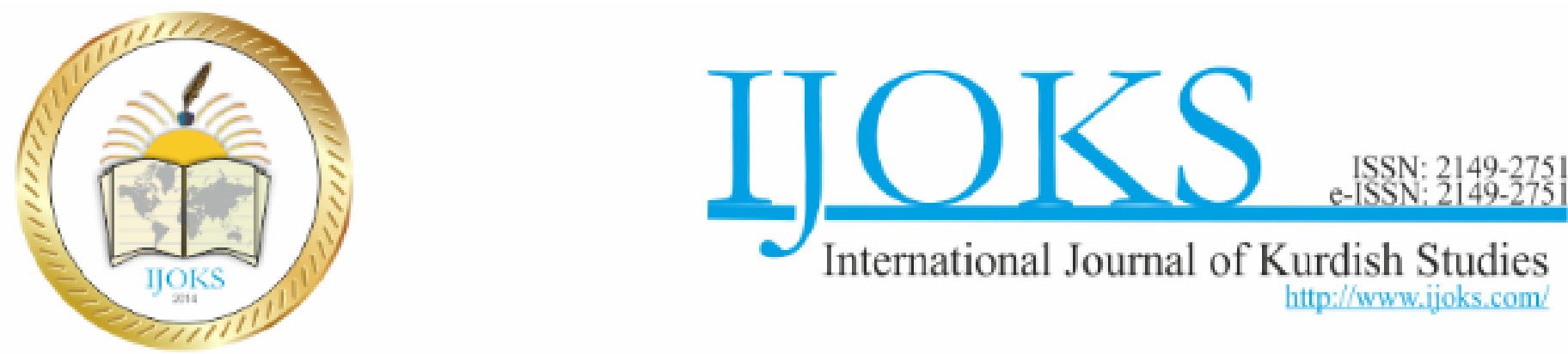

International Journal of Kurdish Studies

http://www.jijoks.com

\title{
Article
}

International Journal of Kurdish Studies

$6(1)$, pp. $35-51$

http://ijoks.com

\section{Kurmanji and Zazaki Dialects: Comparative Study on their Phonetics}

\author{
Hasan Karacan ${ }^{1}$
}

Received: Nov 30, $2019 \quad$ Reviewed: Dec 04, $2019 \quad$ Accepted: Dec 04, 2019

\begin{abstract}
Kurmanji and Zazaki are dialects of the theoretical language known as Kurdish. The various Kurdish dialects affirm the dialectical richness of the word and its sound, and show no indication of a decline in the spoken language. In general, the phoneme is thought to indicate the proximity or remoteness of language or its dialects Kurdish is considered to date far back into antiquity. The present study is divided into three parts. It aims to reveal some phonetic characteristics of Kurmanji and the older dialect, Zazaki. The first part deals with the actual sounds of the phonemes; the second part is on the interchangability of sounds in the Zazaki of different regions; and the third part compares Kurmanji to Zazaki, making use of modern linguistic resources in systems of language.
\end{abstract}

Keywords: Kurmanji, Zazaki, Kurdish phonetics, Structuralism, Sorani, Kurdish Dialects

\section{Recommended citation:}

Karacan, H. (2020). Kurmanji and Zazaki Dialects: Comparative Study on their Phonetics.

International Journal of Kurdish Studies 6 (1), 35 - 51

DOI: https://doi.org/10.21600/ijoks. 653812

\footnotetext{
${ }^{1}$ Ph.D, Diyarbakir / Turkey, E-mail: $\underline{\text { h_karacan@hotmail.com }}$
} 


\section{Introduction}

Structuralist theory, attributed to the linguist Ferdinand de Saussure (1857-1913) is accepted as being a language system. As a structuralist, de Saussure distinguishes between what he calls langue and parole (language and word, that is, unarticulated structures and speaking). He himself as a linguist focusses on langue rather than parole. Langue and parole would later be reinterpreted as signifier and the signified, and in particular the literary theorist Roland Barthes (1915-1980) in working within the science of semiotics, and thus focussing on signs, the signified, would again find de Saussure's structuralist distinction to be crucial. From here, when reducing structuralism down to its various elements, we find that the smallest element spoken is a sound unit that the science of phonetics calls a phoneme, and that although we may be able to pronounce and relate to 200 sound units, speakers use only 40 such elements for thousands of words (Kiran, 1996: 27).

Each word or sound entity has its own unique root meaning, and in the Kurdish dialects we see that each sound entity has its own essential sense - or unrelated senses. Ultimately, the unit of sense that we call language, is then formed by bringing together words within the language system structure. This unit of sense delivers a message. It should, however, be borne in mind that as I.A. Richards wrote:

Language, well used, is a completion and does what the intuitions of sensation by themselves cannot do. Words are the meeting points at which regions of experience which can never combine in sensation or intuition, come together. They are the occasion and the means of that growth which is the mind's endless endavour to order itself. . . Language is no mere signalling system (The Philosophy of Rhetoric. London: Oxford University Press, pp. 130-131).

Sounds and words in Kurdish dialects are not fixed. A further glance at Kurdish dialects also tells us that actual vocabulary is retained, but that the same vocabulary is used in different ways as time progresses. Thus, we have ended up with an extensive vocabulary to say, for example, the "sense of smell": vinî, zincî, pirrnike, pirnos, poz, vinike, difn, bêvil, kepoz, lut, birnax; or, we can mean "catarrh" using the words, zekem, bapêş, persî, şobe, asirm, zikam, peta, miqaw, nezle, baper; or, we can use the following words to say "root": kok, reh, bineke, resen, rêl, rîşe, retewe, binetu, rek, binye, reya, rîçik (Veroj, Uçaman, 2002: 146). 
Sometimes the way a word is voiced, that is uttered, changes, and the change in voicing causes a new word to evolve; this manner of change is an important feature of Kurdish. For example, we have the word kin, that becomes also nik, lêr / rêl, befr / berf, pirasî / pars $\hat{u}-$ and there are many more such examples to be found. Moreover, as said above, with the emergence of structured language, sounds become subject to change in terms of how they are voiced and word formation itself can be influenced. As a result of such changes in voicing, differing language structures come to the fore.

A sound is a sensory perception of vibrations, which is to say that we perceive sound through our sense organs. Phonetics researches the physics of utterance (Oğur, 2014: 35). Words are uttered when sounds merge. Every vibration adds meaning to language, as well as creating differentiation between the words. For example, the vibrations in our mouth and throat may be distinguished or described as languagal sounds. When we alter the ultimate vibrations of the words, the meaning may not be affected, or scarcely affected, but when we change the initial vibrations, the meaning of the word will be different. For example, when changing the words roj and rozruz - the "j" and "z" sound of roj, or the "o," "û," "u" of rozruz - the meaning is not changed. However, if we attach meaning to words such as pîr, bîr, vîr, tîr, nîr, jîr, jar, war, mar, har, we will not understand the new vibrations.

Thus, the aim of phonology is to answer such questions as "what changes sounds and effects differentiation in meaning; how elements that cause differences shift; and, how vibrations coincide with the establishment of vocabulary (Rifat, 2000: 44). It is at this point that phonetics emerges in a field of grammatical study known as antagonism.

\section{The Sounds in Zazaki and Kurmanji}

The vibrations in Indo-European languages ring clear and loud (Ward, 2006: 249). Kurmanji and Zazaki likewise have strong vibrations. Every utterance becomes meaningful according to the physical variations and tone in the phsionomy of the speaker. In recent times both Zazaki and Kurmanji are written down and recorded in a 31-letter adaptation of the Latin alphabet. It is worthy of note that another major Kurdish dialect, Sorani, uses the Arabic alphabet which is closer to being a phonetic representation, and appeals to a more élite readership.

The additional letters of the Latin alphabet include: h (hhê, hhêl), x / ğg (ğar, ğele), and there are eight vowels and twenty-three consonants. 
Vowels: a, e, ê, i, î, o, û, u.

The vowels are described as being "long" or "short."

The long vowels are: a, ê, $\hat{1}, \mathrm{o}, \hat{\mathrm{u}}$.

The first letter of the alphabet is the phoneme A-a. Both Zazaki and Kurmanji read "a" straight, long and wide. "A" comes out of the larynx cavity with ease - without tongue, jaw, tooth or lip contact (Uçaman, 2008: 16). See below comparative table of Zazaki / Kurmanji:

Zazaki Kurmanji

Aw av

Asmên asman

Adir agir

Û. û: This letter comes out of the back of the throat and is read round, narrow and long. A few examples are given below:

Zazaki Kurmanji

Dûr dûr

Mû mû

Hûrdî hûr

O-o: This letter comes from the back of the throat and is read long, round and wide; it can also come before and after other vowels.

\section{Zazaki Kurmanji}

Ox ox

Oxir oxir

Lorik lorik

Î-î: This letter is formed at the front of the tongue and is read in a long, narrow and flat manner.

Zazaki Kurmanji

Îsot îsot

Mîr mîr 
Karacan Kurmanji and Zazaki Dialects: Comparative Study on their Phonetics

Sîr sîr

ÊE-ê: It is formed on the front part of the tongue and is read long and flat.

Zazaki Kurmanji

Êre êvar

Êzim êzing

Mêrdek mêrik

The short vowels are: e, i, u.

These letters are read the same way in both Zazaki and Kurmanji.

E-e: This letter is read plainly and briefly. It may come before or after a consonant.

$\underline{\text { Kurmanji Zazaki }}$

Erd erd

Dev fek

Ser ser

I-i: This letter is read the same way in both Zazaki and Kurmanji. It is read straight, short and narrow.

$\underline{\text { Zazaki Kurmanji }}$

Çirê çima

Birik birek

Bize bizin

U-u: This letter is round and narrow. Words starting with this letter are few in number.

Zazaki Kurmanji

$\begin{array}{ll}\text { Kulav } & \text { kulav } \\ \text { Kulm } & \text { kulm } \\ \text { Xulam } & \text { xulam }\end{array}$

Consonants: b, c, ç, d, f, g, h, j, k, l, m, n, p, q, r, s, ş, t, v, w, x, y, z. 
The consonants can be divided into four parts according to their mouth exit.

a) Consonants that come in contact with the lower lip and the upper lip in contact with each other: $b, f, m, p, v, w$.

Zazaki Kurmanji

$\begin{array}{ll}\text { Berz } & \text { bilind } \\ \text { Ferd } & \text { fer } \\ \text { Mar } & \text { mar } \\ \text { Pel } & \text { pel } \\ \text { Veng } & \text { vala } \\ \text { Wişk } & \text { hişk }\end{array}$

b) Consonants resulting from the contact of the teeth with each other: d, l, n, s, t, z.

Zazaki Kurmanji

Dar dar

Lehî laser

Name nav

Say sêv

Tarî tarî

Zuwa zuha

c) Consonants formed by the contact of the front part of the stem and the tongue: c, ç, ş, j, y

Zazaki Kurmanji

$\mathrm{Ca} \quad$ cî

Çem çem

Şew Şev

Jahr jahr

Yewndes yanzdeh

d) The vowels from the throat: $h, q, x$

Zazaki Kurmanji

Hak hêk 
Qelew qelew

Xençer xençer

e) Consonants from the distance: $\mathrm{g}, \mathrm{k}$

Zazaki Kurmanji

$\mathrm{Ga} \quad \mathrm{ga}$

Kehan kevn

Voiced "r," "rr" actually report motion - "r," "rr" are in both Zazaki and Kurmanji. In general, "rr" is read between two vowels or when used after a vowel. Some examples are:

Zazaki Kurmanji

$\begin{array}{ll}\text { Bar } & \text { bar } \\ \text { Rem } & \text { rev }\end{array}$

Rûven rûn

Pirr pirr

Virr $\quad$ virr/derew

Birrnayîş $\quad$ birrîn

(Kurdo, 1991: 21, Bedirxan \& Lescot, 2009: 4)

\section{Change of some sounds according to regions in Zazakî}

Kurmanji is stable where words that alternatively take the sounds of "b" and "v" in Zazaki vary according to region. Some examples are:

Pîran Dersim Cewlig

Hesab hesav hesav

Kitab kitav kitav

Yewbin zuvin yobîn/juvin

Xirabe xirave xirawe

(Yilmaz, 2015, Veroj \& Uçaman, 2002).

Zazaki pronunciation variants are the letters "z, "j," "y" and "c." Celadet Ali Bedirxan writes: "There are in essence two types of Zazaki. The distinctive sounds and rules are self-evident. 
As regards sound, "j" is seen in the Siverek vernacular, but not in Kurmanji. In some words, "j" is not used with the Palu - "z" or "c" being used instead:

Zazaki Palu

$\begin{array}{ll}\text { Mij/miz } & \text { Zewac/zewaz } \\ \text { Nêzdî/nijdî } & \text { Yewbin/jewbin/zuvin } \\ \text { Mizgîn/mijdane } & \text { Yewna/jewna } \\ \text { Roj/roz/ruc } & \text { Ziwa/jiwa } \\ \text { Berzîn/berjîn } & \text { Jew/yew }\end{array}$

(Bedirxan, 1998: 23)

Voiced to unvoiced is common in Zazaki. Words that take the "k" and "ç" in the Dersim vernacular and other regions vary.

\section{$\underline{\text { Pîran/Çermug Dêrsim }}$}

$\begin{array}{ll}\text { Keye } & \text { çeye keyna } \\ \text { Çeynakeber/ber } & \text { çeber Kêf çêf }\end{array}$

The voiced "ş" used in Zazaki's other regions is pronounced as "s" in the Dêrsim vernacular, as for example:

Weş/wes Derguş/dergus $\quad$ Şeş/ses $\quad$ Şima/sima Şew/sew

The consonants "c" and "g" are interchangable in other Zazaki vernaculars. Examples are:

$\mathrm{Gan} / \mathrm{can}$

Geno (girewotiş)/cêno

Bigîr/bicîgêrayene/cêreyane

"a" > "o": This is a sound event that occurs when a flat tone of voice, known as rounding, becomes a round voice - a common sound event in Persian and Zazaki. For example, the word "bread" in Persian and Zazaki nan, can be pronounced as "non" and "nun" in daily conversation (Oğur, 2014: 51). This occurs not only with Zazaki vernaculars but also with Kurmanji and Zazaki as "a," "û," "o" and "u." Examples are: 
Çar/çor

Maker/moker/mûnker

Varan/varon/varûn
Çend/çond

Giran/giron/girûn
Manga/monga(moga/munga)

Panc/ponc/ponj/pûnc

Zazaki root words often add suffixes to indicate whether or not the words are masculine or feminine. Especially feminine words are written in this way. When these suffixes are encountered, we should take care not to confuse the simple form with the affixes.

Zazaki Kurmanji

Dar/dare dar

Dew/dewe gund

Şew/şewe şev

Biz/bize bizin

Her/here (mankere) $\quad$ ker

Par/pare par

As mentioned above, the sounds "l," and "r" in Kurdish dialects are interchangable. Similarly, with Zazaki, the "l," and " $r$ " voices of Zazaki's versification are interchangable.

Mîrçike/mîlçike Rojine/lojine Zerr/dil/dill/zil/şêrzil

Velg/berg Emserr/emal Perçîn/pelçîn

Qereçî/qeleçî

\section{Phonetic Comparison of Zazaki and Kurmanji Dialects}

As mentioned earlier, the smallest element of the language is the phoneme. Sometimes words come together only with one sound and sometimes with more than one sound. According to dialect, vernacular, and region, speakers utter the sound that is natural and easy for them. Consequently, the nature of the word itself along with changes to the word suit ongoing situations. "V" can take the place of the frontal voiced "b" consonant. Going back in history to the Iranian languages, the word vafra (snow) in Avesta - in Zazaki becomes vor, in Kurmanji ber, in Persian barf. Similarly, vata (wind) in Avesta becomes $v a$ in Zazaki, and $b a$ in Kurmanji, in Persian bad. Bad occurs again as vast in Zazaki, bist in Kurmanji, and bîst in Persian (Oğur, 2014: 51) - in Avesta vit (twenty). 
The consonants "b," "v" and "m" are variants of many words in Zazaki and Kurmanji. For example, instead of Zazaki's "v" sound, in Kurmanji we may see "b" and sometimes "p." Further examples are as follows (Farqini, 1992, http://ferheng.org/tr/):

Zazaki Kurmanji

$\begin{array}{ll}\text { Vewr } & \text { berf } \\ \text { Velg } & \text { belg } \\ \text { Vîst } & \text { bîst } \\ \text { Vîr } & \text { bîr } \\ \text { Va/yay } & \text { ba } \\ \text { Varan } & \text { baran } \\ \text { Vaz } & \text { baz } \\ \text { Vela } & \text { bela } \\ \text { Verapey } & \text { berûpaş } \\ \text { Virso } & \text { birûsk } \\ \text { Venikyayîş } & \text { ponijîn } \\ \text { Zimistan } & \text { zivistan } \\ \text { Zama } & \text { zava } \\ \text { Xam } & \text { xav }\end{array}$

"V-v" is widely used in Zazaki and Kurmanji, but in Piran Zazaki the "w" sound is used instead of the "v" sound.

Zazaki Kurmanji

Aw av

Şew şev

Awî avî

Lew lêv

Baw bav

"M" can evolve into a fricative semi-consonant as "v." Thus we have gâm (step) in Avesta, in Zazaki gam, in Kurmanji gav, in Persian gam. Naman (name) in Avesta, in Zazaki is namê, in Persian nam, but in Kurmanji is nav (Ogur, 2014: 52). Some other examples are as follows: 
Karacan Kurmanji

Nîme/nême nîv

Zama zava

Hamnan havîn

Zimistan zivistan

The "X- $\mathrm{x}$ " sound is present in all the Kurdish dialects, and is loud from the larynx. When the "x" and "w" sounds are used in the background, they are uttered as the diphthong "xw." Words starting with the diphthong "xw" create softening in Zazaki, and the " $\mathrm{x}$ " in front of the "w" voice falls - as in the following examples:

Zazaki Kurmanji

Wer $\quad$ xwar

Werden $\quad$ xwarin

Weş $\quad$ xweş

Nêweş nexweş

Wele xwelî

Waye $\quad$ xwah

Wendene $\quad$ xwendin

The "j" sound in Kurmanji becomes "z" or "c" in Zazaki. There are also variants among Zazaki’s regional vernaculars.

$\underline{\text { Zazaki } \quad \text { Kurmanji }}$

$\begin{array}{ll}\text { Bazar } & \text { bajar } \\ \text { Cêr } & \text { jêr } \\ \text { Cinî/cenî } & \text { jin } \\ \text { Cena/cenayene } & \text { jentin } \\ \text { Vace } & \text { bêj } \\ \text { Roj-roz/ruz } & \text { roj } \\ \text { Zî } & \text { jî̀ } \\ \text { Mezg } & \text { mejî }\end{array}$


Kurmanji words with "h" and Zazaki words with "h" and "ş" vary. Examples of these variants are as follows (http://ferheng.org/tr/):

$\underline{\text { Kurmanji }}$

Rohnî

Sihur/sor

$\mathrm{Reh} / \mathrm{rê}$

Pahtin

Goh/go

$\operatorname{Mih} / \mathrm{mî}$

Tihnî
Zazaki

$$
\text { roşna/roşnayî }
$$

sur

rayir

pewtene

goş

mêşna

têşanê

"H-h" is one of the oldest sounds of Kurdish. In today's Zazaki and Kurmanji, the "h" falls into the middle of the range of voices, with the " $h$ " sound tending to get lighter. Some examples of this are as follows (http://ferheng.org/tr/, Veroj \& Uçaman, 2002):

$\underline{\text { Kurmanji }}$

Fireh/fire

Şeh/şe

Goh/go

Mih/mî

Hêş/êş

Hêvar/êvar

Dergahvan/dergavan

Mêhman/meyman

Mirhov/mirov

\section{Zazaki}

hambaz/ambaz

hestor/estor

havil/avil

herê/erê

herey/erey

heynî/eynî

hewnîya/ewnîya

mêhvan/mêvan

rehwan/rewan

Another characteristic ongoing change with Zazaki and Kurmanji is that the old utterance of "d" common among the Kurdish peoples continues to exist as in Zazaki, but that this sound is lost in Kurmanji (Day 2013, Ciwan 2014, Stone 2013). 
Kerd

Kerdene

Berdene

Werdene

Sard

Pird kir

kirin

birin

xwarin

sar

pir

Regarding Zazaki and Kurmanji words with "d," "v," and "g," there are ongoing changes. According to Michael L. Chyet, the letter "g" in Kurmanji responds to the letter "v" in Zazaki and the letter "w" in Hewrami (Chyet, 2005: 109). Some examples are as follows:

$\underline{\text { Zazaki }}$

$\mathrm{Va} / \mathrm{vat}$

Vatene

Veng

Verg

Vil

Veleke
Kurmanji

go/got
gotin
deng
gurg
gul
gurçik

According to Michael L. Chyet, the "r" and "d" sounds have evolved from "l," "z," and "r" previously "1." This holds for both Kurdish and Persian (Chyet, 2005: 110).

$\underline{\text { Zazaki }}$

Zerr

Çar/çewres

Sare/sere

Serdar

\section{Kurmanji}

dil

çil/çihel

sal

serdar/salar

In Kurmanji, the "d" voice as initial consonant of indicative verbs changes to the voice " $t$ ":

Derim / terim, dixum / texum, dikim / tekem, dihêm / têm

Words that have "y," "w," and "h" in Zazaki and Kurmanji dialects vary. These sounds also play a role in integration. 

Kurmanji

Giya giha

Siwar siyar

Wûrdek hûrdek

Hûrdî hûr

Wirdî/herdi herdu

Wişk hişk

In some places the sound of "e" changes to "y":

Esri / yesir (captive), Exte / yexte (workhorse)

Onomatopoeia, the formation of words from a sound associated with what is named, was clearly well-established in antiquity! Thus, we come across words calling to mind torrents and streams using "l," or "r" and "s" (Porzîng, 1990: 21). Relevant examples are as follows:

Zazaki Kurmanji

$\begin{array}{ll}\text { Lehî } & \text { laser } \\ \text { Pêl } & \text { pêl } \\ \text { Lêl } & \text { şêlo } \\ \text { Liv } & \text { liv } \\ \text { Ing } & \text { ling } \\ \text { Rem } & \text { rev } \\ \text { Herik } & \text { herik } \\ \text { Ray } & \text { rê } \\ \text { Rayan } & \text { rêwî } \\ \text { Rişna } & \text { rijand } \\ \text { Neseb } & \text { neseb } \\ \text { Ro } & \text { robar } \\ \text { Pilor } & \text { pilor }\end{array}$

(Farqini, 1992, Veroj \& Uçaman, 2002) 
As said above, Dersim Zazaki voices are quite commonplace. If after the voice of the dull fricative dental "s" we have "î," the "s" becomes "ş": wes > weşî, kes > keşî, hes > heşî (Oğur, 2014: 51).

To reiterate, both the words of Zazaki and Kurmanji and the words of Zazaki's vernaculars are undergoing change (http://www.hakkarim.net/cgibin/yenisozluk.cgi/goste\#üst):

$\begin{array}{ll}\text { Zazaki } & \text { Kurmanji } \\ \text { Raşt } & \text { rast } \\ \text { Rişte } & \text { riste } \\ \text { Rişt } & \text { rist } \\ \text { Rişten } & \text { ristin } \\ \text { Rişna } & \text { rijand }\end{array}$

\section{Conclusion}

Kurdish, as do other world languages, resolves into dialects. That is to say, the existence of different dialects is assumed to be a historical reality for all languages. In the case of Kurmanji and Zazaki, the closeness or distance of one to the other is relative to the proximity or distance of the other dialects to each other. In general, these phenomena should be viewed positively, which is to say, the dialects yield an ongoing wealth of vocabulary, richness in sound, and infinite possibilities for expression and 'stretching the language' so-to-speak.

With the help of the science of phonetics, the proximity or distance between the various dialects can be determined. Indeed, the similarities between Zazaki and Kurmanji show that there is more dialectical closeness than that between two languages, and that we are left with only the similarities between two dialects. Moreover, we are left with no doubt that in general the dialects of Kurdish offer more similarities than differences. This reinforces the assumption that cultural and historical phenomena surrounding the dialects evolve from what is an original Kurdish language and culture from far back in antiquity. 


\section{References}

Bedirxan, Celadet Ali, (1998). Elfabêya Kurdi, Bingehên Gramera Kurdmanci. İstanbul. Doz Yayınc1lik

Bedirxan, Celadet Ali\&Lescot Roger, (2009). Gramera Kurdî. İstanbul. Avesta Yayıncıllı.

Bedirxan, Celadet Ali, (1998). Hawar, h. 23, Çapkerdişê Weşanê Nûdem, Stocholm

Chyet, Michael L. (2005). Rûpelek ji Dengsazîya Dîrokî ya Zimanê Kurdî, Kovara Bîr, hej. 3

Ciwan, Murad, (2014). Türkçe Açıklamalı Kürtçe Dilbilgisi, Diyarbakır

Culler, Jonathan, (1983). Barthes. Fontana Modern Masters: Great Britain.

Culler, Jonathan, (1976). Saussure. Fontana Modern Masters: Great Britain.

Farqini, Zana, (1992). Ferhenga Kurdi-Tirkî. İstanbul Kürt Enstitüsü Yayınları.

Gündüz, Deniz, (2013). Kırmanca/Zazaca Dil Dersleri, İstanbul. Vate Yayınları.

Kappagoda, Astika Kautilya (July 2004). Semiosis as the Sixth Sense: Theorising the Unperceived in Ancient Greek (Ph.D. Thesis on systemic functional linguistics). Macquarie University, Sydney, Australia, Department of Linguistics. Online: http://www.isfla.org

Karacan, H. \& Kaya, B. (2015). Zazaki ile Kurmanci lehçelerinin fonetik yönünden karşılaştırılması [Phonetic comparison of the Kurmanci and Zazaki dialects]. International Journal of Kurdish Studies 1 (2), pp.102 - 115.

DOI: $10.21600 /$ ijoks. 106020

Karacan, H. \& Khalid, H. S. (2016). Adjectives in Kurdish language: Comparison between dialects.International Journal of Kurdish Studies 2 (2), 15 - 23. DOI: https://doi.org/10.21600/ijks.76230

Kurdo, Qanatê, (1991). Gramera Zimanê Kurdî: Kurmancî-Soranî. İstanbul. Koral Yayınları. Kıran, Zeynel, (1996). Dilbilim Akımları. Onur Yayınları.

Oğur, Serkan, (2014). Farsça, Zazaca, Kurmanca Mukayeseli Gramer Ve Temel Sözlük, İstanbul. Yazılama Yayınları.

Öktem, Filiz, (2015). Uygulamalı Latin Dili, İstanbul. Kabalcı Yayınları.

Özel, Çeto, (2012). Kürtçe Dil ve Eğitim Hakları, İstanbul. Kurdistan Yayınları

Porzîng, Walter, (1990). Dil Denen Mucize, cild:1 Ankara. Kültür Bakanlığı Yayınları.

Rıfat, Mehmet, (2000). XX. Yüzyılda Dilbilim ve Göstergebilim Kuramları, İstanbul. Kuram Yayınları

Taş, Çetin, (2013). Waneyên Rêziman û Rastnivîsa Kurmancî, İstanbul. Diwan Yayınları 
Uçaman, Abdurrahman, (2008). Ferhenga Etimolojiya Zimanê Kurdi, Weşanên Bîr, Diyarbekir,

Veroj, Seid, (2008). Veracêkerdena Gramerê Zazakî û Kurmancî: Dîyalekt, Alfabe û Fonetîk, Morfolojî Veroj, Seid-Uçaman, Abdurahman, (2002) Ferheng-Vajname: KurmanjiHewramani-DımıliSenendaji, İstanbul. Weşanên War,

Ward, Paul Von, (2006). Tanrılar, Genler ve Bilinç, İstanbul. Kozmik Yayınları.

Yılmaz, Abdurrahman, (2015). Zazaca-Türkçe Sözlük (Bingöl-Genç Yöresi), Yüksek Lisans Tezi. http://ferheng.org/tr/, Date of access: 11.08.2015 http://www.hakkarim.net/cgibin/yenisozluk.cgi/goste\#üst, Date of access: 16.08.2015 